\title{
A GeNDER PERSPECTIVE ON CAREER PREFERENCES AND ENTREPRENEURIAL SELF-EFFICACY
}

Author:

Boris Urban ${ }^{1}$

\section{Affiliation:}

${ }^{1}$ Wits Business

School, University of

Witwatersrand,

South Africa

\section{Correspondence to:}

Boris Urban

email:

boris.urban@wits.ac.za

\section{Postal address:}

Wits Business

School, University of

Witwatersrand, PO Box 98,

Wits 2050, South Africa

\section{Keywords:}

Entrepreneurship;

intentions; self-efficacy;

women

\section{Dates:}

Received: 19 Apr. 2010

Accepted: 30 Jul. 2010

Published: 28 Oct. 2010

How to cite this article:

Urban, B. (2010). A

gender perspective

on career preferences

and entrepreneurial

self-efficacy. SA Journal

of Human Resource

Management/SA Tydskrif

vir Menslikehulpbronbestuur,

8(1), Art. \#293, 8 pages. DOI:

10.4102/sajhrm.v8i1.293

\section{This article is available}

at:

http://www.sajhrm.co.za

(C) 2010. The Authors.

Licensee: OpenJournals

Publishing. This work

is licensed under the

Creative Commons

Attribution License.

\begin{abstract}
Orientation: Gender perspectives on entrepreneurship illustrate that women are less likely than men to prefer those occupations which have been traditionally male-dominated, because of the tendency for women to have lower self-efficacy perceptions in relation to entrepreneurial career intentions.

Research purpose: The objective of this study was to establish to what extent women perceive self-employment as a viable career choice and how strong their beliefs are that they are capable
\end{abstract} of successfully performing various entrepreneurial roles and tasks.

Motivation for the study: The study is relevant because national studies indicate that the ratio of female to male participation in entrepreneurial activity varies considerably across countries.

Research design, approach and method: A survey design was used, with responses being based on quantitative measures. Measures were tested for validity and reliability. Descriptive statistics were calculated and differential tests were conducted to test the relevant hypotheses.

Main findings: The results of the study showed that women believe that they have the skills needed to be an entrepreneur and have placed their preference for entrepreneurship as a career choice high on the list of options.

Practical/managerial implications: Human resources managers and educators must recognise that 'a one-size-fits-all' approach to training and development might not be appropriate and that gender-sensitive programming, especially in relation to different levels of entrepreneurial selfefficacy might be required.

Contribution of study: The study contributes to the growing knowledge base on women entrepreneurship and increases our understanding of entrepreneurship as a viable career choice in terms of entrepreneurial self-efficacy.

\section{INTRODUCTION}

Differences persist in the levels of new firm creation across genders, with international studies indicating that the number of women involved in starting a business is significantly and systematically lower than that of men (Bosma \& Levie, 2009; Langowitz \& Minniti, 2007). Research supports the supposition that men and women follow different business start-up processes. Women are more likely than men to balance work and family roles, to handle conflict and to consider time and space constraints as they create new firms (Brush, 1992; Carter et al., 2003; Havenga, 2009). In general, men are more likely to start a business than are women. In no country are women more active in starting and owning a business than are men (Langowitz \& Minniti, 2007; Minniti, Bygrave \& Autio, 2005)

In South Africa, women comprise up to $52 \%$ of the adult population, of which $41 \%$ are considered to be part of the active working population. South Africa's early-stage total entrepreneurial activity index, the primary measure, which is used to compare the rate of new business start-ups amongst countries, was found to be relatively low (5.90\%) for 2009 (Bosma \& Levie, 2009). The profile of those who are categorised as entrepreneurs in terms of the specified index indicates that approximately $7.5 \%$ are men and 5.0\% are women (Bosma \& Levie, 2009). Even though the ratio between male and female entrepreneurs in South Africa is not highly disproportionate, the majority of South African women entrepreneurs operate within the crafts, hawking, personal services and retail sectors, in which sectors little technology is utilised in the undifferentiated businesses concerned (Maas \& Herrington, 2006). Such a finding clearly suggests that some form of gender division of labour still persists in South Africa, with women still being locked into traditional female functions, tending to concentrate on those activities which are compatible with their domestic and reproductive roles (Mahadea, 2001). Moreover, women entrepreneurs tend to have a Grade 12 or lower educational qualification, which might explain the lack of exploitation of higher order entrepreneurial opportunities. In terms of education, women are also less likely to pursue such technical disciplines as engineering and computer science, which would provide them with much needed skills for launching successful businesses in manufacturing and high-technology sectors (Botha, Nieman \& Van Vuuren, 2007; Carter \& Brush, 2004).

Experts believe that entrepreneurial activity is affected by the attitudes of those groups which are discriminated against and by cultural practices which hinder the development of entrepreneurship in South Africa (Orford et al., 2003). Not only is a negative individual mindset often mentioned as a hindrance to entrepreneurship, but it is also evident that entrepreneurship is not viewed as a legitimate career choice, with insufficient education and training heading the list of obstacles to 
entrepreneurial development (Driver et al., 2001). More than $50 \%$ of South African women entrepreneurs were found to think that they were not entrepreneurial in nature, whereas a relatively low (9\%) percentage of them expressed the belief that they were entrepreneurial in nature (Maas \& Herrington, 2006).

\section{Research purpose}

Particularly important to the present study is that, apart from demographic and economic variables, a number of perceptual variables have been found to have a crucial influence on the entrepreneurial propensity of women and might account for much of the difference which is found between the sexes in regard to their entrepreneurial activity. Specifically, women tend to perceive both themselves and the entrepreneurial environment in a less favourable light than do men across countries, regardless of their entrepreneurial motivation. Such findings suggest that perceptual variables might be significant universal factors that influence entrepreneurial behaviour (DeTienne \& Chandler, 2007; Wilson, Kickul \& Marlino, 2007). Attitudes influence behaviour by impacting on intentions. Intentions and attitudes depend on the situation and person concerned (Scherer et al., 1989). By coming to an understanding of entrepreneurial perceptions, our understanding of intended behaviour increases.

Moreover, there is an underexplored and unarticulated female set of processes and behaviours that influences new venture creation (De Bruin, Brush \& Welter, 2007). Although a separate theory of women entrepreneurship might not be required, existing theoretical concepts, which are normally used in trying to explain women entrepreneurship, could be expanded to include explanations of the distinctiveness of women entrepreneurship (De Bruin et al., 2007; Eddleston \& Powell, 2007).

In South Africa, given the high priority of employment in government economic policies and the pertinence of entrepreneurial activity to job creation (Autio, 2005), empirical research into women entrepreneurs and entrepreneurial intentions and self-belief is urgently required. Currently, in South Africa, most research and policy initiatives focus on necessity entrepreneurs (those individuals who are selfemployed as a result of having no other choice), who have emerged from the unemployed masses. Although such micro enterprises or survivalists have entrepreneurial characteristics, their ability to grow and create employment is restricted by their scarcity of skills, their business knowledge and their resources (Pretorius \& Van Vuuren, 2002). The present study differs from the prevailing trend by specifically focusing on women entrepreneurs who are more likely to be self-employed because of them pursuing a business opportunity, rather than because they have to. Although opportunity-driven entrepreneurs are responsible for only a small proportion of all entrepreneurial activity in South Africa, they are responsible for up to $80 \%$ of all job creation by entrepreneurs (Autio, 2005)

\section{Research objective}

A broad objective of the current study is to learn about entrepreneurship in general by studying women entrepreneurs rather than men. Bird and Brush (2002) draw our attention to gender perspectives on entrepreneurial processes, illustrating that gaining a different viewpoint will add to our knowledge on how individuals perceive and operationalise entrepreneurship. Venture creation is gendered in and of itself, with the historical focus being on male processes and behaviours. There is some doubt as to whether current research approaches and methodologies adequately incorporate the 'reality' of women entrepreneurship. It has been suggested that research into women entrepreneurship contributes both in terms of its scholarly outlook and in terms of the contribution that it makes to society (Wilson et al., 2007)
The research objectives of this paper draw on the emerging body of knowledge about women entrepreneurship. Given the lack of empirical evidence of the differences in entrepreneurial activity between the sexes, the research objectives of this paper are to determine to what extent women, in comparison with men, perceive self-employment as a viable career choice and to establish the levels of their beliefs regarding their selfefficacy in relation to their successful performance of various entrepreneurial roles and tasks.

\section{Gender differences}

The theoretical framework of social feminism helps to explain gender differences in human capital, positing, as it does, that there are differences in male and female experiences from the earliest moments of life, which result in men and women having fundamentally different ways of viewing the world (DeTienne \& Chandler, 2007; Fischer, Reuber \& Dykes, 1993). Basically, social feminism views the genders as different but equal and proposes that differences between women and men are due to unique socialisation processes (DeTienne \& Chandler, 2007). These distinctive experiences allow men and women to develop unique human capital, which, in turn, impacts on the identification of entrepreneurial opportunities (Eddleston \& Powell, 2007; Venkataraman, 1997).

The social feminist view is often contrasted with the liberal feminist view, which contends that men and women are equal, autonomous individuals. Based on such a perspective, women have been denied critical resources (e.g. financing, networks) for establishing new ventures, with the elimination of discriminatory practice resulting in the establishing of equal opportunities for women (DeTienne \& Chandler, 2007). Bird and Brush (2002), by drawing on feminist approaches, propose a model, in terms of which gender is regarded as impacting on entrepreneurial processes in terms of differences which are emphasised between men and women in connection to reality, time, action and interaction and power and ethics.

Notwithstanding the above-mentioned feminist views, little analysis has yet taken place regarding how gendered processes affect entrepreneurial behaviour, or shape the size of firms. The tendency of men entrepreneurs, in relation to women entrepreneurs, to focus on growing their business has, also, to be examined. Most research into women entrepreneurship has not been based on feminist theories, tending to result in gender differences being explained in terms of how women entrepreneurs deviate from a so-called 'male norm'.

What emerges from the different viewpoints mentioned above is that, although it has been argued that there are no psychologically justified reasons for believing that women entrepreneurs might have fewer intentions of starting a venture, liberal and social feminist theories do provide sociocultural explanations for expecting gender differences in this regard (Cliff, 1998).

\section{Women entrepreneurship}

Based on a literature review of 400 academic articles on women entrepreneurs by Carter, Anderson and Shaw (2001), the indications are that several studies investigate specific gender differences in terms of business management, finance, business networks and performance. Generally, most descriptive studies, especially those with small and convenience samples that describe research which has been undertaken into the personal characteristics of women entrepreneurs have found more similarities than differences between them and their male counterparts (Gatewood et al., 2002; Mahadea, 2001).

Research which has been undertaken into the impact of differences in gender on career choices has also shown the existence of important discrepancies between the two genders. For instance, women have been found to experience more complexity in their career choices than do men, because 
of the former's need to balance their work and family roles (Carter et al., 2003). In terms of business characteristics, women entrepreneurs have been found to tend to set up their ventures with lower start-up capital than have men and the ventures concerned have generally been found to be smaller in size in comparison with those ventures which are owned by men (Brush, 1992).

Multiple studies have examined the access to capital and venture capital funding of women entrepreneurial firms. With regard to financing, previous research shows that womenowned businesses tend to start with both lower levels of overall capitalisation and lower ratios of debt finance than do menowned businesses (Bosma \& Levie, 2009; Carter \& Allen, 1997; Coleman, 2000).

Results from a national survey of women entrepreneurs in Malawi indicate that the relationship between gender and business performance is a complex one; female-owned enterprises were found to tend to grow more rapidly in terms of employment opportunities than did male-owned ones (Chirwa, 2008). Gender differences in network structures and networking behaviour have also been reported, with social capital being found to influence both the decision to start and grow a business, as well as business survival and success (Manolova et al., 2007).

Not only does research show that women's intentions in launching a new business might differ from those of men (Carter \& Brush, 2004), but that self-efficacy, attribution, work values, decision-making and motivational theories all may help to explain why gender differences lead to differential self-employment choices. Several researchers have indicated that women are less likely than are men to prefer occupations which have been traditionally male-dominated, because of the tendency for women to have lower self-efficacy perceptions in relation to the occupations concerned (Baughn et al., 2006; Hackett et al., 1992; Wheeler, 1983). Gender plays a significant role in business performance, insofar as it influences the selfperceptions of entrepreneurs and their abilities to realise business start-up and growth (Anna et al., 2000). Raising entrepreneurial efficacies should raise perceptions of venture feasibility for women entrepreneurs, thus increasing their perceptions of opportunity recognition (Wilson et al., 2007), as well as self-efficacy perceptions that are pivotal to entrepreneurial intentions (Scherer et al., 1989).

\section{Role of self-efficacy in entrepreneurial intentions}

Several academic efforts are directed towards exploring the reasons that entrepreneurs offer for starting a new business, indicating that new ventures start-ups are not accidental, but are, rather, entrepreneurial actions, which are clearly intentional (Carter et al., 2003; Wilson et al., 2007). Starting a business, or initiating a new venture, is often described as a purposive and intentional career choice, with the role of entrepreneurial selfefficacy (ESE) emphasised as a key antecedent (Chen, Greene \& Crick, 1998). Since self-efficacy reliably predicts the scope of career options considered, occupational interests, perseverance in difficult fields and personal effectiveness, it has been related to the pursuit of entrepreneurial activity (Markman, Balkin \& Baron, 2002). Perceived self-efficacy is the strongest single predictor of career choice (Bandura, 1986) and self-reported competencies predict entrepreneurial performance (Chandler \& Jansen, 1992). Correlations between self-efficacy and career intent range from 0.3 to 0.6 , which is better than most predictors used in entrepreneurial research, such as locus of control (Bandura, 1986, 1997).

The value of understanding entrepreneurial self-efficacy is particularly useful, since it incorporates both personality and environmental factors and is thought to be a strong predictor of entrepreneurial intentions and, ultimately, action (McGee et al., 2009). Moreover, individuals' cognitive preferences for analysis or intuition influence their perception and assessment of entrepreneurial self-efficacy (Kickul et al., 2009).

Investigating the effect which attitudes have on intention to start a business, Douglas and Shepherd (2002) found that the intention to be an entrepreneur is stronger for those with more positive attitudes to risk and independence. Perceived feasibility is consistently correlated with self-efficacy in most intention-based models (Krueger, Reilly \& Carsrud, 2000). Such findings suggest that entrepreneurs must have perceptions of high self-efficacy to be able to cope with the challenges of modern society.

Based on the research findings on self-efficacy, which has been theoretically and empirically linked to intentions, hypotheses are formulated, in terms of which entrepreneurship as a career choice is examined in terms of entrepreneurial self-efficacy for men versus women, with the role of gender proposed as a differentiating factor.

\section{Hypotheses}

Seeing that perceptual variables have been found to have a crucial influence on entrepreneurial intention and may account for much of the difference in entrepreneurial activity between the sexes, it is proposed that:

H1: Entrepreneurship as a career choice will be significantly less likely for women than for men.

H2: Entrepreneurial self-efficacy will differ significantly more for women than for men.

\section{RESEARCH DESIGN}

\section{Research approach}

The study is cross-sectional and survey-based in design. Such a design will suitably resolve the main research question and address the limitations of previous studies by empirically testing hypotheses in those areas where much speculation exists.

A quantitative methodology was used to identify career preferences and entrepreneurial self-efficacy, with the methodological stance being supported in previous investigations with similar focus areas (Boyd \& Vozikis, 1994; Chandler \& Jansen, 1992; Chen et al., 1998; Earley, 1994; Krueger \& Brazeal, 1994). Seeing that responses are solicited in a manner which allows for quantitative analysis, nothing in the nature of the data will prevent the emergence of deeper speculations and insights.

Another design issue concerns the types of measures which are used in research into women's entrepreneurship. This is a construct validity question. For instance, if measures of entrepreneurship are created in terms of male-owned businesses and male entrepreneurs and if we accept that there are gendered aspects to entrepreneurship, we may be missing certain aspects of women's entrepreneurship that are both positive and value creating and from which we may learn more about entrepreneurship generally (Wilson et al., 2007). This contention is addressed in the present study by means of the application of analytical techniques used to test for construct reliability and validity.

\section{Research method}

\section{Participants}

Given the psychological nature of the constructs examined in the current study, precedent exists for utilising student samples for such research even within management and entrepreneurship literatures. It has been suggested that research into intention using students allows for the improvement of predictive abilities, providing a fertile ground from which seeds of entrepreneurship can sprout. Research finds that student 
samples are very similar to those of actual entrepreneurs, provided that the former have high entrepreneurial potential (Fayolle et al., 2005; Hemmasi \& Hoelscher, 2005; Reynolds et al., 2003). Graduates tend to start more ventures, grow bigger ventures and accumulate more assets (Charney \& Libecap, 2004; Peterman \& Kennedy, 2003). Since individuals embarking on entrepreneurial careers and who are very close to the creation of new enterprise, typically have high self-efficacy levels, by evaluating the entrepreneurial beliefs of such subjects prior to the creation of new enterprise, the study is more likely to have validity in terms of intention (Gartner, 1989). Also, by using students for the envisaged study it will be possible to eliminate the possibility that prior success in venture formation will have influenced the respondent's self-efficacy beliefs (Scherer $e t$ al., 1989).

The population of the study is the new public higher education landscape in South Africa, consisting of 23 universities, with approximately 725000 students (Hesa, 2009). In the higher education system concerned, the proportion of head count student enrolments in each of four major study fields for the year 2007 was:

- science, engineering and technology $=28 \%$

- business and management $=30 \%$

- education $=14 \%$

- other humanities $=28 \%$

The proportion of head count student enrolments in each gender group for the year 2007 was:

- $\quad$ female $=56 \%$

- male $=44 \%$

The above figures show the growing predominance of women student enrolments in the higher education system during the past few years (Hesa, 2009).

To allow for meaningful comparisons, only students in business and management study fields were surveyed, limiting the sampling frame to faculties preoccupied with such studies. The faculties concerned have various nomenclatures at the different higher education institutions, such as Faculty of Management, Economic Management Sciences, or Economic Financial Sciences Faculty. Over 500 students at four different higher education institutions, ranging in type from university to comprehensive university to university of technology, were surveyed, in the Johannesburg and Pretoria geographical areas, due mainly to practical and cost constraints. To ensure statistically valid sample numbers from each gender group, quota sampling was used, rendering a final sample of 213 usable responses. The use of this sampling approach allowed for matching of different gender groups.

The sample characteristics were based on an equal distribution of men $(50 \%)$ and women $(50 \%)$, with a mean age of 21.13 years, with $100 \%$ of respondents having completed matric and being full-time undergraduate students. Additionally, the majority of respondents (61.2\%) indicated that they had parents, friends or relatives who are, or had been, entrepreneurs.

\section{Measuring instruments}

The measures were based on previous conceptualisations of entrepreneurial self-efficacy, particularly as measuring self-efficacy of a broader domain, such as entrepreneurship, requires researchers to develop a conceptual framework of task requirements on the basis of which self-efficacy of a domain is aggregated from self-efficacy of various constituent subdomains. Adapting measures developed by Chen et al. (1998), De Noble, Jung and Ehrlich (1999) and, more recently, Wilson et al. (2007), entrepreneurial self-efficacy was measured across varying entrepreneurial roles and tasks, coinciding with Chen et al.'s (1998) dimensions of marketing, innovation, management, risk-taking and financial control.

The entrepreneurial self-efficacy construct has previously demonstrated and predicted the likelihood of an individual choosing entrepreneurship as a career preference. Moreover, entrepreneurial self-efficacy refers to the strength of a person's belief that he or she is capable of successfully performing various roles and tasks of an entrepreneur. A key point in the efficacy approach to occupational preference is that these perceptions of personal abilities may be more critical than are actual abilities (Bandura, 1997).

The first part of the survey focused on career preferences. Several different occupations were measured on a five-point numerical scale ranging from 'would not prefer to be in this occupation' (scale value of 5) to 'would prefer very much to be in this occupation' (scale value of 1). Numerical scales have equal intervals, with anchors serving as labels for the extreme points (Cooper \& Schindler, 2001). Respondents selected a number from the scale next to each career preference. Numerous career preferences were provided, including: finance, marketing, international business, management, entrepreneurship, business strategy, accounting, e-commerce and management information system. Based on the variety of items surveyed, the scale provides both an absolute measure of importance and a relative measure (ranking) of the various items rated.

The second part of the survey focused on entrepreneurial self-efficacy. Respondents were asked for their degree of current competence on each entrepreneurial self-efficacy dimension. Questions were measured on a 1 to 5 Likert scale, with 1 indicating respondents strongly agree to 5 , indicating the respondents' strong disagreement. Although the scales concerned are susceptible to the error of central tendency, there is no conclusive support for choosing a scale with less or more points (Cooper \& Schindler, 2001).

Consistent with previous research on individual differences in entrepreneurship, control variables measuring gender, age, level of education and presence or absence of role models were included. The latter variable is important in the context of entrepreneurial self-efficacy, because those prospective entrepreneurs who know other entrepreneurs are able to notice opportunities and those who think that they know how to start up a business are ten times more likely to be active in doing so than those who do not. Additionally, parental examples of career choices and daily living situations affect the likelihood of a child selecting self-employment (Carter \& Brush, 2004).

\section{Research procedure}

Once permission was obtained to administer the questionnaires and ethical clearance was established with the participating higher education institution, the questionnaires were administered face-to-face in a classroom setting, at the beginning of the term in one academic year. This procedure allowed for control and the achievement of a high response rate, based on the voluntary completion of questionnaires.

\section{Statistical analysis}

The reliability and validity of instruments used to measure beliefs and intentions is tested and, by means of various statistical procedures, survey results are analysed and discussed within the broader framework of women and entrepreneurship. Lastly, the findings are scrutinised to extract any practical and policy implications regarding this emerging and important topic

Although the selected instruments have previously been subjected to factor analysis and satisfactory results were obtained in terms of factor structure (Chen et al., 1998; De Noble et al., 1999; Urban, Van Vuuren \& Owen, 2008), reliability and validity were tested for this specific sample. Descriptive statistics were calculated and the resultant output was split by gender group. Moreover, by applying tests of normality and calculating the Kolmogorov-Smirnov and Shapiro-Wilk statistics, test scores indicated that normality was not violated. Subsequently, hypothesised differences were tested using a simple independent $\mathrm{t}$-test between mean scores. 


\section{RESULTS}

\section{Career preference percentage analysis}

Based on the occupational preference scale, $53.8 \%$ of the total percentage of respondents chose entrepreneurship as a career preference, followed, in order of ranking, by that in marketing (53.4\%), management $(43.7 \%)$, international business $(35.9 \%)$, business strategy $(26.9 \%)$, accounting $(11.2 \%)$, e-commerce $(10.7 \%)$, finance $(9.3 \%)$ and management information systems (7.9\%). An option for 'other' career preferences constituted $18.9 \%$ of the responses received. Table 1 provides an overview of the range of responses, with only the extreme scores displayed in terms of 'would not prefer to be in this occupation' (scale value 5) to 'would prefer very much to be in this occupation' (scale value of 1). Because the scale provides both an absolute measure of importance and a relative measure (ranking) of the career preferences rated, it is interesting to note that entrepreneurship not only has the highest percentage when compared to other career preferences, but that it also has a relatively low percentage $(8.1 \%)$ for not being preferred as a career.

To test hypothesis 1 , in terms of which hypothesis differences on entrepreneurship as a career choice were expected to be significantly lower for women than for men, frequencies were split by gender, indicating that entrepreneurship as a career preference was still higher for men $(63 \%)$ than for women $(37 \%)$. However, for women marketing was ranked as the first preference $(56 \%)$, followed next by entrepreneurship (47\%). To establish whether any significant differences on career preferences exist between male and female respondents, an independent samples t-test was conducted.

A statistically significant difference at the 0.05 level was obtained, supporting the first hypothesis.

\section{Validity and reliability of entrepreneurial self-efficacy measure}

Factor analysis was used to identify the de facto underlying orthogonal dimensions of entrepreneurial self-efficacy evident in the data. The data were initially subjected to Conventional Item and Test Analysis, in terms of which item to total correlation of each item established that items were not correlated. According to Tabachnick and Fidell (2007), orthogonal rotation results in solutions that are easier to interpret and report, provided that the underlying constructs are not correlated. Subsequently, Varimax rotation was used together with Bartlett's test of sphericity, rendering a Kaiser-Meyer-Olkin (KMO) measure of sampling adequacy (0.88), indicating an approximate Chisquare of 2158.64 with 210 degrees of freedom. A KMO value of 0.90 to 1.00 indicates a high degree of common variance, indicating that the items are measuring a common factor.

Table 2 displays the rotated factor matrix results, in terms of which all the entrepreneurial self-efficacy items were factored, resulting in five factors. The respective eigenvalues and percentage of variance and cumulative percentages of each of the factors are reported in Table 3. The rotation method was Varimax with Kaiser normalisation, with the rotation converging in 22 iterations. Factors with loadings greater than, or equal to, 0.30 were considered significant and eigenvalues greater than 1 (based on scree tests and Kaiser's stopping rule) were used to decide on the optimal number of factors to retain. Based on the rotated factor results, the grouping of items reflects the previously established dimensions of entrepreneurial selfefficacy, (1) factor one represents the management subdimension, (2) factor two represents the innovation subdimension, (3) factor three represents the marketing subdimension, (4) factor four represents the financial subdimension and (5) factor five represents the risk-taking subdimension.

Internal consistency was tested and the Cronbach's alpha was calculated for each individual factor by using only those items selected in the sorted rotated factor-loading matrix. Cronbach's alpha has the most utility for multi-scales at the interval level of measurement (Cooper \& Schindler, 2001). The Cronbach's alpha was $0.83,0.83,0.80,0.87$ and 0.73 for factors 1 to 5 respectively. Generally, a value above 0.7 is considered adequate for internal consistency (Nunnally, 1978).

\section{Descriptive statistics}

Diagnostics were carried out to test for normality of data. Results indicate that data were normally distributed, since

TABLE

Percentage analysis of career preferences

\begin{tabular}{lcc}
\hline & Most Preferred & Least Preferred \\
\hline $\begin{array}{l}\text { My career preference is } \\
\text { mostly in finance }\end{array}$ & $9.3 \%$ & $45.6 \%$ \\
$\begin{array}{l}\text { My career preference is } \\
\text { mostly in marketing }\end{array}$ & $53.4 \%$ & $7.3 \%$ \\
$\begin{array}{l}\text { My career preference is } \\
\text { mostly in global business }\end{array}$ & $35.9 \%$ & $10.6 \%$ \\
$\begin{array}{l}\text { My career preference is } \\
\text { mostly in management }\end{array}$ & $43.7 \%$ & $5.3 \%$ \\
$\begin{array}{l}\text { My career preference is } \\
\text { mostly in entrepreneurship }\end{array}$ & $53.8 \%$ & $8.1 \%$ \\
$\begin{array}{l}\text { My career preference is } \\
\text { mostly in business strategy }\end{array}$ & $26.9 \%$ & $8.4 \%$ \\
$\begin{array}{l}\text { My career preference is } \\
\text { mostly in accounting }\end{array}$ & $11.2 \%$ & $63.5 \%$ \\
$\begin{array}{l}\text { My career preference is } \\
\text { mostly in e-commerce }\end{array}$ & $10.7 \%$ & $30.2 \%$ \\
$\begin{array}{l}\text { My career preference is } \\
\text { mostly in management } \\
\text { information systems }\end{array}$ & $7.9 \%$ & $28.3 \%$ \\
\hline
\end{tabular}

information systems

Note: only the two extreme set of ratings are shown.

TABLE 2

Rotated factor matrix on items measuring entrepreneurial self-efficacy

\begin{tabular}{|c|c|c|c|c|c|}
\hline Item & $\begin{array}{l}\text { Factor 1: } \\
\text { Management }\end{array}$ & $\begin{array}{l}\text { Factor 2: } \\
\text { Innovation }\end{array}$ & $\begin{array}{l}\text { Factor 3: } \\
\text { Marketing }\end{array}$ & $\begin{array}{l}\text { Factor 4: } \\
\text { Financial }\end{array}$ & $\begin{array}{l}\text { Factor 5: } \\
\text { Risk }\end{array}$ \\
\hline c16 & 0.725 & 0.250 & -0.026 & 0.144 & 0.224 \\
\hline c17 & 0.665 & 0.110 & 0.154 & 0.153 & 0.141 \\
\hline c19 & 0.597 & 0.006 & 0.335 & 0.009 & 0.356 \\
\hline
\end{tabular}

$\begin{array}{llllll}\mathrm{c} 18 & 0.541 & 0.106 & 0.398 & -0.015 & 0.391\end{array}$

$\begin{array}{llllll}\mathrm{c} 21 & 0.480 & 0.295 & 0.043 & 0.138 & 0.229\end{array}$

$\begin{array}{llllll}\text { c20 } & 0.476 & 0.259 & 0.199 & 0.058 & 0.316\end{array}$

$\begin{array}{llllll}\mathrm{c} 15 & 0.355 & 0.160 & 0.194 & 0.309 & 0.116\end{array}$

$\begin{array}{llllll}\text { c6 } & 0.096 & 0.686 & 0.220 & 0.011 & 0.272\end{array}$

$\begin{array}{llllll}\text { c7 } & 0.081 & 0.670 & 0.355 & -0.097 & 0.273\end{array}$

$\begin{array}{llllll}c 10 & 0.456 & 0.601 & 0.274 & 0.115 & -0.017\end{array}$

$\begin{array}{llllll}\text { c8 } & 0.412 & 0.565 & 0.130 & 0.188 & 0.110\end{array}$

$\begin{array}{llllll}\text { c9 } & 0.447 & 0.524 & 0.212 & 0.204 & 0.103\end{array}$

$\begin{array}{llllll}\text { c13 } & 0.055 & 0.184 & 0.685 & 0.275 & 0.091\end{array}$

$\begin{array}{llllll}\mathrm{c} 12 & 0.118 & 0.405 & 0.658 & 0.169 & 0.192\end{array}$

$\begin{array}{llllll}c 14 & 0.370 & 0.281 & 0.636 & 0.059 & 0.088\end{array}$

$\begin{array}{llllll}c 11 & 0.351 & 0.281 & 0.395 & 0.304 & -0.040\end{array}$

$\begin{array}{llllll}\mathrm{c} 25 & 0.076 & 0.028 & 0.173 & 0.869 & 0.049\end{array}$

$\begin{array}{llllll}\text { c24 } & 0.150 & 0.017 & 0.106 & 0.845 & 0.084\end{array}$

$\begin{array}{llllll}\text { c22 } & 0.404 & 0.187 & 0.222 & 0.064 & 0.745\end{array}$

$\begin{array}{llllll}\text { c23 } & 0.335 & 0.226 & 0.009 & 0.076 & 0.493\end{array}$

$\begin{array}{llllll}\mathrm{c} 26 & 0.162 & 0.206 & 0.083 & 0.413 & 0.492\end{array}$

TABLE 3

Factor eigenvalues and variance explained for entrepreneurial self-efficacy

\begin{tabular}{llll}
\hline Factor & Eigenvalues & \% of variance & Cumulative variance \\
\hline Management & 8.227 & 39.178 & 39.178 \\
Innovation & 1.935 & 9.217 & 48.394 \\
Marketing & 1.682 & 8.011 & 56.405 \\
Financial & 1.143 & 5.442 & 61.847 \\
Risk & 1.105 & 5.260 & 67.107 \\
\hline
\end{tabular}


the means, modes and medians for each question were almost equal. The $\mathrm{Q}-\mathrm{Q}$ plots also supported the normality of the data and the stem-and-leaf plots showed a bell shape, with all the significant values for the items being less than 0.05 .

The measures of central tendencies and dispersion (refer to Table 4) revealed that, apart from factor 4 (financial control) the distributions tailed towards the right (positively skewed) Apart from factor 4 (financial control: $M=3.03$ ), the mean scores for the other factors are relatively mediocre, that is, below the midpoint on the 1 to 5 Likert scale.

Group statistics were then calculated for each factor in terms of gender (refer to Table 5). Mean scores were consistently higher for women on all five factors.

To establish whether any significant differences exist on these factors between men and women, an independent samples t-test for equality of means was carried out, with no significant differences being detected for factor one (management), factor 4 (financial control), or factor 5 (risk-taking). However, factor 2 (innovation) and factor 3 (marketing) t-scores, at 207 degrees of freedom, of 3.38 and 2.24 respectively, were found to be significant at the 0.05 level (refer to Table 6). This significant result provides partial support for hypothesis 2, in terms of which it was expected that entrepreneurial self-efficacy would differ between the sexes.

To establish whether any of the control variables would play a significant role in differentiating male from female respondents, the same procedure was carried out for differences over level of education and age, with no significant results being obtained. Although the results presented above tell us that the difference that we obtained in the two set of scores was unlikely to occur by chance, they do not tell us much about the magnitude of the difference concerned. One way in which to determine the magnitude concerned is to calculate the effect size statistic using Cohen's $d$. Cohen (1988) defines effect sizes as 'small, $d$ $=0.01$,' 'medium, $d=0.06$ ' and 'large, $d=0.14$ '. For our current sample, the magnitude of differences across means was found to be medium (eta squared $=0.06$ )

\section{DISCUSSION}

The principal aim of this paper was to determine to what extent women perceive self-employment as a viable career choice and to determine whether significant differences exist in levels of self-efficacy beliefs in terms of successfully performing the various roles and tasks of an entrepreneur. The empirical results obtained provide partial support for the hypotheses, as in the case of hypothesis 1 , it was postulated that entrepreneurship as a career choice would be significantly lower for women than for men. In terms of hypothesis 2 , significant gender differences were detected for only two of the five factors measuring entrepreneurial self-efficacy, providing partial support for that hypothesis. Specifically, the findings indicate that women score significantly higher than do men on the innovation subdimension of entrepreneurial self-efficacy, as well as on the marketing subdimension of such self-efficacy. A plausible explanation for the significant differences observed in terms of the two entrepreneurial selfefficacy factors is that both innovation and marketing involve some degree of creativity, in terms of which female respondents might have an advantage. Self-efficacy has been identified as a key motivational component in individual creative action (Bandura, 1997). Previous empirical studies indicate that men tend to place a greater emphasis on economic values and on quantitative non-ambiguous measures, such as status and wealth, whereas women tend to assign more importance to social values and qualitative, ambiguous measures, such as personal fulfilment and strong interpersonal relations (Cliff, 1998; DeTienne \& Chandler, 2007)

Interlinking the empirical results of this paper with established literature allows for additional insights to emerge. The findings resonate with the premise that women tend to have lower entrepreneurial career aspirations in comparison with those of men. Prior literature has suggested that women generally suffer from a gender effect, that is, in terms of inferior entrepreneurial aspirations and lower expectations (Manolova et al., 2007). To some degree, the present study confirms such tendencies, though it also dispels the myth that women tend not to select entrepreneurship as a career choice and that they lack the requisite beliefs to be able to perform in entrepreneurial careers. While entrepreneurial career aspirations were significantly lower for women in comparison with those for men, entrepreneurial career preferences were ranked second highest in terms of career choice. Additionally, in terms of the requisite beliefs to perform in entrepreneuria careers, as measured in terms of entrepreneurial self-efficacy, the mean scores were consistently higher for women on all of the entrepreneurial self-efficacy subdimensions. While gender stereotypes were not directly measured in this study, the finding that female respondents selected a career path which was historically dominated by men and that their self-efficacy score was found to be higher across all the entrepreneurial selfefficacy factors, indicates that the sample of potential female entrepreneurs concerned perceive themselves as capable and willing to be entrepreneurial.

The present study adds to the growing knowledge base on different types of entrepreneurship and increases our understanding of the important relationship between entrepreneurship and gender. As noted by Eddleston and Powell (2007), the effects of gender are not limited to the biological effects of sex, but rather, gender identity is a better predictor of entrepreneurial career intentions than the former are. Individuals develop a sense of themselves by means of the social categorisation process and, because sex is a highly visible

TABLE 4

Descriptive statistics for entrepreneurial self-efficacy factors

\begin{tabular}{lllll}
\hline Factor & $\boldsymbol{M}$ & s.d. & Skewness & Kurtosis \\
\hline Management & 2.296 & 0.641 & 0.542 & 0.593 \\
Innovation & 2.074 & 0.737 & 0.966 & 1.243 \\
Marketing & 2.283 & 0.713 & 0.520 & 0.666 \\
Financial & 3.036 & 0.977 & -0.012 & -0.290 \\
Risk & 2.032 & 0.757 & 1.076 & 1.883 \\
\hline
\end{tabular}

d., standard deviation.

TABLE 5

Descriptives for entrepreneurial self-efficacy factors per gender

\begin{tabular}{llll}
\hline Factor & Gender & $\boldsymbol{M}$ & s.d. \\
\hline Management & Male & 2.226 & 0.702 \\
& Female & 2.344 & 0.594 \\
Innovation & Male & 1.870 & 0.696 \\
& Female & 2.214 & 0.735 \\
Marketing & Male & 2.151 & 0.734 \\
& Female & 2.374 & 0.686 \\
Financial & Male & 2.911 & 1.017 \\
& Female & 3.122 & 0.948 \\
Risk & Male & 1.984 & 0.786 \\
& Female & 2.066 & 0.738 \\
\hline
\end{tabular}

s.d., standard deviation.

TABLE 6

T-test: independent comparison of entrepreneurial self-efficacy factors between gender groups

\begin{tabular}{|c|c|c|c|}
\hline Factor & $t$ & $d f$ & Sig. (2-tailed) \\
\hline Management & 1.97 & 207 & 0.10 \\
\hline Innovation & 3.38 & 207 & 0.04 \\
\hline Marketing & 2.24 & 207 & 0.05 \\
\hline Financial & 1.77 & 207 & 0.09 \\
\hline Risk & 1.68 & 207 & 0.06 \\
\hline
\end{tabular}


basis for self-categorisation, individuals identify with personal traits and beliefs that are attributed to men rather than with those attributed to women.

The results of the study could have implications for educational initiatives, in terms of recognising that a 'one-size-fits-all' approach to curricula may not be appropriate and gendersensitive programming, especially in relation to different levels of entrepreneurial self-efficacy, coupled with building women's entrepreneurial aspirations, might be required (Wilson et al., 2007). With the growth in educational programmes designed to provide skills and abilities for entrepreneurship, comes the opportunity to better understand what works and what does not and to establish best programme practices. Research suggests that, whereas venture creation resources are relatively scarce in transition economies, entrepreneurship education programmes in both the East and West need to place more emphasis on developing skills related to venture resource gathering (Mueller \& Goic, 2003).

The current study makes a contribution to the field of women entrepreneurship, in which few empirical studies exist in an emerging country context. The study is particularly relevant, as national studies indicate that the ratio of female to male participation in entrepreneurial activity varies considerably across countries, reflecting the impact of different cultures and customs on female participation in economic activity (Bosma \& Levie, 2009)

\section{Limitations and future research}

Although no claims of representativeness of the South African population are made, the study's sample characteristics do reflect the general population demographic at higher education institutions in South Africa, allowing for findings to be extrapolated, albeit with caution, to other students at such institutions. The study has typical survey design limitations. Since it was cross-sectional, the results should be interpreted with caution and gender differences in unmeasured variables might have influenced the results. Another limitation concerns the statistical testing, as, with this type of analysis, there is always the possibility of reaching the wrong conclusion. Consequently, the study is subject to Type 1 and Type 2 errors, which are endemic to this type of analysis and which are well documented in the literature (Cooper \& Schindler, 2001).

As a directive for future research and action, a proposition is made: Rather than suggest that women must be more widely represented in terms of entrepreneurship and in the natural sciences (so that they appear to be more like men), it seems more realistic to assume that there may be a unique role for both men and women to play in the field of such endeavour. Accordingly, the results of the current study could be interpreted as supportive of the social feminist view, in terms of which one gender does not have to become more like another in order to succeed, but rather, each individual should focus on the importance of developing his or her own individual resources (i.e. ESE) (DeTienne \& Chandler, 2007). Growing the role of women in entrepreneurship to the detriment of male entrepreneurs will not provide the appropriate impetus for the accelerated socio-economic growth of South Africa. Therefore, it will be necessary to enlarge the economic cake before both men and women entrepreneurs can have their full share of it (Maas \& Herrington, 2006)

\section{CONCLUSION}

Based on the empirical results obtained in the research described in this article, the current study helps to explain female career preferences. By combining the preliminary evidence with the findings of previous research on career aspirations and entrepreneurial self-efficacy, it can be deduced that entrepreneurship is no longer perceived as a male-orientated field of pursuit, and that young women have entrepreneurial career aspirations, because they have been found to believe they have the necessary competencies to be entrepreneurial in nature.

\section{REFERENCES}

Anna, A.L., Chandler, G.N., Jansen, E., \& Mero, N.P. (2000). Women business owners in traditional and non-traditional industries. Journal of Business Venturing, 15(3), 279-303.

Autio, E. (2005). Report on high-expectancy entrepreneurship: Global entrepreneurship monitor. Babson: HEC Lausanne.

Bandura, A. (1986). Social foundations of thought and action: A social cognitive theory. New Jersey: Prentice-Hall.

Bandura, A. (1997). Self-efficacy: The exercise of control. New York: W.H. Freeman \& Company.

Baughn, C., Cao, J., Le, L., Lim, V., \& Neupert, K. (2006). Normative, social and cognitive predictors of entrepreneurial interest in China, Vietnam and the Philippines. Journal of Developmental Entrepreneurship, 11(1), 57-77.

Bird, B., \& Brush, C. (2002). A gendered perspective on organisational creation. Entrepreneurship Theory and Practice, 26(3), 41-65.

Bosma, N., \& Levie, J. (2009). Global entrepreneurship monitor: 2009 global report. Babson Park: Babson College.

Botha, M., Nieman, G., \& Van Vuuren, J. (2007). Measuring the effectiveness of the women entrepreneurship programme on potential, start-up and established women entrepreneurs in South Africa. South African Journal of Economic and Management Sciences, 10(2), 163-183.

Boyd, N.G., \& Vozikis, G.S. (1994). The influence of self-efficacy on the development of entrepreneurial intentions and actions. Entrepreneurship Theory and Practice, 18(4), 63-78.

Brush, C. (1992). Research on women business owners: Past trends, a new perspective and future directions. Entrepreneurship Theory and Practice, 16, 05-26.

Carter, N., \& Allen, K. (1997) Size-determinants of womenowned businesses: Choices or barriers to resources. Entrepreneurship and Regional Development, 9(3), 211-220.

Carter, N.M., \& Brush, C.G. (2004). Gender: Demographic characteristics of the entrepreneur. In W.B. Gartner, K.B. Shaver, N.M. Carter \& P.D. Reynolds (Eds.), Handbook of entrepreneurial dynamics, (pp. 12-25). Thousand Oaks, CA: Sage Publications.

Carter, N.M., Anderson, S., \& Shaw, E. (2001). Women's business ownership: A review of the academic and popular and Internet literature. Report to the Small Business Service. Glasgow: University of Strathclyde.

Carter, N.M., Gartner, W.B., Shaver, K.G., \& Gatewood, E.J. (2003). The career reasons of nascent entrepreneurs. Journal of Business Venturing, 18, 13-39.

Chandler, G.N., \& Jansen, E. (1992). The founders self-assessed competence and venture performance. Journal of Business Venturing, 07, 223-236.

Charney, A.H., \& Libecap, G.D. (2004). Impact of entrepreneurship education. Academy of Management Learning and Education, September, 340-342.

Chen, C.C., Greene, P.G., \& Crick, A. (1998). Does entrepreneurial self-efficacy distinguish entrepreneurs from managers? Journal of Business Venturing, 13, 295-316.

Chirwa, E.W. (2008). 'Effects of gender on the performance of micro and small enterprises in Malawi', Development Southern Africa, 25(3), 347-362.

Cliff, J.E. (1998). Does one size fit all? Exploring the relationship between attitudes towards growth, gender, and business size. Journal of Business Venturing, 13, 523-542.

Cohen, J. (1988). Statistical power analysis for behavioural sciences. (2nd Edn.). New Jersey: Erlbaum, Hillside.

Coleman, S. (2000). Access to capital and terms of credit: A comparison of men and women-owned small businesses. Journal of Small Business Management, 38(3), 37-52.

Cooper, D.R., \& Schindler, P.S. (2001). Business research methods, (7th Edn.). Singapore: McGraw-Hill. 
De Bruin, A., Brush, C.G., \& Welter, F. (2007). Advancing a framework for coherent research on women's entrepreneurship. Entrepreneurship Theory and Practice, May, 323-339.

De Noble, A.F., Jung, D., \& Ehrlich, S.B. (1999). Entrepreneurial self-efficacy: The development of a measure and its relationship to entrepreneurial action. Frontiers of Entrepreneurship Research. Babson Park, MA: Babson College.

DeTienne, D.R., \& Chandler, G.N. (2007). The role of gender in opportunity identification. Entrepreneurship Theory and Practice, 25(4), 81-99.

Douglas, E.J., \& Shepherd, D.A. (2002). Self-employment as a career choice: Attitudes, entrepreneurial intentions and utility maximization. Entrepreneurship Theory and Practice, Spring, 81-90.

Driver, A., Wood, E., Segal, N., \& Herrington, M. (2001). Global entrepreneurship monitor: South African executive report. Cape Town: University of Cape Town.

Earley, P.C. (1994). Self or group? Cultural effects of training on self-efficacy and performance. Administrative Science Quarterly, 39, 89-109.

Eddleston, K.A., \& Powell, G.N. (2007). The role of gender identity in explaining sex differences in business owners' career satisfier preferences. Journal of Business Venturing, 4 $1-13$.

Fayolle, A., Gailly, B., Kickul, J., Lassas-Clerc, D., \& Whitcanack, N. (2005). Capturing variations in attitudes and intentions: A longitudinal study to assess the pedagogical effectiveness of entrepreneurship teaching programs. In the 50th Annual Conference of the International Council for Small Business, June 2001 (pp. 15-20), Washington D.C., United States of America.

Fischer, E.M., Reuber, A.R., \& Dykes, L.S. (1993). A theoretical overview and extension of research on sex, gender, and entrepreneurship. Journal of Business Venturing, 8, 151-168.

Gartner, W.B. (1989). Some suggestions for research on entrepreneurial traits and characteristics. Entrepreneurship Theory and Practice, Fall, 27-37.

Gatewood, E.J., Shaver, K.G., Powers, J.B., \& Gartner, W.B. (2002), Entrepreneurial expectancy, task effort, and performance. Entrepreneurship Theory and Practice, Winter, 187-206.

Hackett, G., Betz, N., Casas, J., \& Rocha-Sinjh, I. (1992). Gender, ethnicity and social cognitive factors predicting achievement. Journal of Counselling Psychology, 39, 527-538.

Havenga, W. (2009). Gender and age differences in conflict management with small businesses. South African Journal of Human Resource Management, 6(1), 22-28.

Hemmasi, M., \& Hoelscher, M. (2005). Entrepreneurship research, using students as proxies for actual entrepreneurs. In the 50th Annual Conference of the International Council for Small Business, June 2001 (pp. 15-20), Washington D.C., United States of America.

Hesa, 2009, Pathways to a diverse and effective South African higher education system, Retrieved February 03, 2010, from http:// www.hesa.org.za.html

Kickul, J., Gundry, L.K., Barbosa, S.D., \& Whitcanack, L. (2009). Intuition versus analysis? Testing differential models of cognitive style on entrepreneurial self-efficacy and the new venture creation process. Entrepreneurship Theory and Practice, March, 439-453.

Krueger, N.F., \& Brazael, D.V. (1994). Entrepreneurial potential and potential entrepreneurs. Entrepreneurship Theory and Practice, 18, 91-105.

Krueger, N.F., Reilly, M.D., \& Carsrud, A.L. (2000). Competing models of entrepreneurial intentions. Journal of Business Venturing, 15, 411-432.
Langowitz, N. \& Minniti, M. (2007). 'The entrepreneurial propensity of women'. Entrepreneurship Theory and Practice, 31(3), 341-365.

Maas, G., \& Herrington, M. (2006). Global entrepreneurship monitor: South African report. Graduate School of Business. Cape Town: University of Cape Town.

Mahadea, D. (2001). Similarities and differences between male and female entrepreneurial attributes in manufacturing firms in the informal sector in the Transkei. Development Southern Africa, 18(2), 189-199.

Manolova, T.S., Carter, N.M., Manev, S., \& Gyoshev, B.S. (2007) The differential effect of men and women entrepreneurs' human capital and networking on growth expectancies in Bulgaria. Entrepreneurship Theory and Practice, 31(3), 407-427.

Markman, G.D., Balkin, D.B., \& Baron, R.A. (2002). Inventors and new venture formation: The effects of general selfefficacy and regretful thinking. Entrepreneurship Theory and Practice, 27, 149-165.

McGee, J.E., Peterson, M., Mueller, S.L., \& Sequeira, J.M. (2009). Entrepreneurial self-efficacy: Refining the measure. Entrepreneurship Theory and Practice, May, 01-24.

Minniti, M., Bygrave, W.D., \& Autio, E. (2005). Global entrepreneurship monitor: Executive report, Babson Park, MA: Babson College.

Mueller, S.L., \& Goic, S. (2003). East-West differences in entrepreneurial self-efficacy: Implications for entrepreneurship education in transition economies. International Journal of Entrepreneurship Education, 1(4), 613 632.

Nunnally, J.C. (1978). Psychometric Theory (2nd edn.). New York: McGraw-Hill.

Orford, J., Wood, E., Fischer, C., Herrington, M., \& Segal, N. (2003). South African executive report update: Global entrepreneurship monitor. Graduate School of Business. Cape Town: University of Cape Town.

Peterman, N.E., \& Kennedy, J. (2003). Enterprise education Influencing students' perception of entrepreneurship. Entrepreneurship Theory and Practice, 28, 129-144.

Pretorius, M., \& Van Vuuren, J. (2002). The contribution of support and incentive programs to entrepreneurial orientation and start up culture in South Africa. In South African Entrepreneurship and Small Business Association Conference, 04-06 June 2002. Sun City, South Africa.

Reynolds, P.D., Bygrave, W.D., Autio, E. et al. (2003). Global entrepreneurship monitor: Executive Report. Babson Park, MA: Babson College

Scherer, F.R., Adams, J.S., Carley, S.S., \& Wiebe, F.A. (1989) Role model performance effects on development of entrepreneurial career preference. Entrepreneurship Theory and Practice, 13, 53-71.

Tabachnick, B.G., \& Fidell, L.S. (2007). Using multivariate statistic (5th Edn.). Boston: Pearson Education.

Urban, B., Van Vuuren, J., \& Owen, R. (2008). Antecedents to entrepreneurial intentions: Testing for measurement invariance. South African Journal of Human Resource Management/ SA Tydskrif vir Menslikehulpbronbestuur, 6(1), 01-09.

Venkataraman, S. (1997). The distinctive domain of entrepreneurial research. Advances in Entrepreneurship, Firm Emergence and Growth, 03, 119-138.

Wheeler, K.G. (1983). Comparisons of self-efficacy and expectancy models of occupational preferences for college male and females. Journal of Occupational Psychology, 56, 73-78.

Wilson, F., Kickul, J., \& Marlino, D. (2007). Gender, entrepreneurial self-efficacy, and entrepreneurial career intentions: Implications for entrepreneurship education. Entrepreneurship Theory and Practice, 13, 387-406. 